\title{
Representation of Iraqi War between Fantasy and Reality in Rajiv Joseph's Bengal Tiger at Baghdad Zoo: A New Historicist Reading
}

\author{
Gihan Samy Ibrahim Al Basuony, M.A.
}

Damietta University, Faculty of Arts, Egypt

doi: 10.19044/esj.2016.v12n29p323 URL:http://dx.doi.org/10.19044/esj.2016.v12n29p323

\begin{abstract}
Rajiv Joseph's Bengal Tiger at the Baghdad Zoo is among the plays which represent the Iraqi war- a prominent event in postmodern history. The play is based on a real story which happened in the Bagdad Zoo when some American soldiers killed a rare Bengal tiger. It is a documentation of this real story and it includes real names and historical places and characters, which make it qualified as a documentary play. The present paper employs the new historicist method in its attempt to show how much the play is a representation of the culture that motivates the actions, whether it is the culture of the author or that of the characters concerned, Arabs and Americans. Thus, the play could be seen both as a product of the interaction of the American culture and the Arab culture that it came in touch with. The American soldiers first saw this war as a mission of freedom, while the Iraqis saw it as ruin of their culture. However, the dramatic method reflects changes in perspectives as the characters come into contact. In this way, the present reading is a chance to understand cultural and intellectual history through literature and mutual influence of cultures.
\end{abstract}

Keywords: Iraq, ghosts, animalism, culture, new historicism

\section{Introduction}

The contemporary era has witnessed many social, economic, and political events such as wars and recent revolutions. All these events form the material of postmodern history and literature at the same time, since the relation between literature and history is a mutual one. The invasion of Iraq is one of the most striking historical events. It has stirred the interest of the entire world in many aspects and challenges. This, however, include both the literary fictional field and the non-fictional fields on the other hand, including history. There are many different opinions concerning the decision 
of war. As a political decision, it has stirred a lot of struggles among political circles or parties. It has also enriched the literary field and conveyed a path for a great area of fiction and nonfiction writings. Many correspondents have returned from war and registered their own experiences and that of their fellow in Iraq. Moreover, many novelists and dramatists have depicted these events. The theatrical phenomenon, known as documentary drama, deals with Iraqi war and generates many plays, such as Guantanamo: Honour Bound to Defend Freedom by Gillian Slovo and Victoria Britain, Stuff Happens and Vertical Hour by David Hare, Mottortown by Simon Stephens and others.

Consequently, the plays which depict Iraqi war include both real and figurative characters. They also contain imagined and real places and events. So, the Iraqi war is both reality and fiction. It is an imagined experience depicted in a literary world, which is an artifact according to the supposition of New Historicism. The depiction of contemporary historical reality is branded "documentary drama" or "docudrama". From this point, this research seeks to focus on those three dimensions. In addition, it takes into consideration the fact that the text examined is a documentary, representing the same point in history as much as it is seen as mediation between history and literature. The research tries to trace the figurative representation of the Iraq war as a historical event and mutually reads the in-between realities as they are represented figuratively in the play. It is an attempt to find how realities - reflected in the political speeches, articles of professional analyzers, critics and even ordinary people - find parallel expression in the play.

The main assumptions of new historicism are much related to documentary drama. Evaluating drama through the hermeneutic concepts of new historicism would be helpful in tracing how the cultural atmosphere is reflected in the literary text. Some of the concepts offered by new historicists may be fruitfully adapted to the reading of the text examined in the recent study.

Bengal Tiger at Baghdad Zoo revolves around the interaction among two American soldiers in Iraq in 2003, two years after the invasion, an Iraqi translator, Bengal tiger from the Baghdad zoo, and other Iraqi citizens. The play explores several themes such as murder, rape, cultural differences, theft, and post-traumatic stress of war. It is a metaphysical drama which mixes the utopian and dystopian in order to urge self-reflective questions about humanity and human being. Subsequently, it is a Meta narrative on Iraq war about the tragicomic consequences of war. Joseph's story of the tiger is a documentary play because it is based on a real event and a real story published in the newspapers. Joseph referred to this point in his interview with Gerald Raymond. Joseph declares that "The initial impulse was a small 
article at the back of the paper about an incident at the Baghdad zoo that I read in 2003."

Bengal Tiger delves into many complex philosophical issues. All of these ideas or themes circulate on human's life conflicts. The play's philosophical ground relates the two sides of conflict: the human desires and traits such as greed, jealousy, fear, power and revenge which lead to war, and on the other side, the perilous effect of war which robs man of his humanity. Joseph's aim matches with his choice of the place which is literally suitable because he chooses a real setting of a tormented country at war. Joseph seems to use the strategy of the game of hide and seek in order to design his play. However, the play is full of ghosts. Also, every character haunts the killer after the death of that character. The play is a show about the puzzling absurdities of war. The awfulness of war is depicted, since even the beast did not evade the fate of death. Joseph tries to present a case for every theme in his play. For example, Musa is the ordinary Iraqi citizen who is the victim of governments. Tom is the type of the American man who is the product of the material culture. Musa is a victim of the tyranny of both Uday and the occupation of the American. Tom believes that he must take compensation for his lost hand in the war. Uday is tyrant and destructive both in his life and death.

New historicism is one of the trends of the contemporary literary criticism. It is first advocated by Stephen Greenblatt in his book The Power of Forms and the Forms of Power in the Renaissance. New historicism is a reaction to reject the ideas of some previous movements of literary criticism, yet it borrowed from others such as Deconstruction and Post structuralism. Unlike Formalism, new historicism rejects the view of text as selfcontained. Also, Feminism did not offer distinct method to serve as an 'agent for social change.' New historicism appeared "to methodize the political interpretation of literature" (Myers 1, 1988). The main idea through which new historicism emerged is that history does not enfold the objective truth about persons, past events, and eras. As a result, it refutes old historicism. Charles E. Bressler says "literature may not be that different from other cultural discourses or 'voices', each voice contributing to and affecting the other discourses" (184,2011). New historicism investigates the interplay of discourses and the social meanings in the time and place in which text was written. New historicism assumes that the historical conditions which generate the literary text are considered as the context. In addition, it is equally important as the text itself.

Joseph uses the facts of the tiger story as an idea or the focal point for what can be described as a magical realist fantasy. He uses nonrealistic style and surreal elements in depicting real story. His characterization suits the 
reality of the event depicted in his play. Also, there were many characters that died or lose their limbs.

Documenting real life in a play is the essence of docudrama. On the other hand, new historicism sees docudrama as both a mirror of the present, yet it is being affected with the past and it is affecting the future. Myers states that "the larger purpose of New Historicist inquiry is the reconstruction of the actual (as opposed to the "represented") relations in which people lived during a particular time" $(31,1988)$. Henceforth, such literary works are "'representations' of the culture from which they emerge" $(31,1988)$. Myers gives details that according to New Historicism;

fiction is defined as the lens through which a certain portrait of the human experience is brought into focus. And as mediation rather than as imitation of social practices, it can thus be said to shape rather than to reflect an age's $\{$ sic $\}$ understanding of human experience and potentiality. (31-32, 1988)

Joseph resorts to expressionist techniques when dealing with his play Bengal Tiger; namely, considering the play and making savagery as its moving force and controlling metaphor. First, he allows the tiger to talk about how lions escaped from the Baghdad zoo in a symbolic reference to the outbreak of violence. It is well known that expressionism depends, in its depiction of reality, on emphasizing specific sides or traits of the characters typical of the art of caricature. Hence, it involves the use of ticket names that sum up characters such as 'tiger'. Second, the theme of the outbreak of violence is again symbolized in a multilayered pattern that includes both humans and animal alike. If lions are set loose in Baghdad streets, this simply means that violence and savagery are the dominant aspects. It is again a new historicist touch since the incident is recorded in the then newspapers and has been handled in news bulletins. Third, Joseph engages both animals and humans in a round of savagery and fight which ends up in favour of human beings, who manage to overcome animals in the game of hunting and massacre. Here, Tiger was used to make reference to Uday Saddam Hussein's son, as 'Tiger of Tigris' (Act 1, Sc.1.p.150). Of course, Joseph set the real tiger and lions in comparison with Uday, the human tiger. The comparison is very clear and suggestive. Both are viewed as wild and heartless in the game of death. Both killed many humans. However, Uday could have outnumbered real tigers in the killing and destruction of human souls.

This point is historically significant, since the fight of good and evil is as old as time itself. People either side with good and get closer to angels or side with evil and get closer to vicious animals. Adam's son, Cane, killed the good-hearted Abel. Here, the tiger spirit showed itself and dominated the 
scene. Throughout history, human tigers existed and astonished us with their unbelievable wildness and barbarous nature. In King Lear, Lear is the monarch who is represented as a foolish old man who divides his kingdom among his daughters and deprives his virtuous girl, Cordelia. Lear's heart was full of kindness towards his people and his three daughters, yet he committed an act of foolishness when he gave authority to his daughters, Goneril and Regan. As a result, he deprived the honest Cordelia of her due share of the kingdom. Subsequently, Goneril and Regan proved to be the prototypes of Uday and copies of Cane. All share the same savage nature that dreams of authority and which force to crush and devastate others.

It is no simple coincidence that King Lear refers to Goneril and Regan as "The shame of Ladies; Tigers not daughters." It is now doubtless that they are seen to belong to the animal world rather than the human world. Thus, they showed no mercy or respect to an old father and monarch in agony. We have to remember that this is a hideous crime for the Elizabethan, the crime of Patricide. It is now clear that Uday is called "Tiger of Tigris" (Act 1, Sc.1, P.150), and King Lear's daughters was known as 'tigers not daughters.' Hence, the cycle is still going on up till now. The same authority, that rendered Goneril and Regan wild, made Uday an equally savage brutal tiger, sharing the same nature of the real ones.

Fourth, Joseph emphasizes that brutal force is blind. It does not distinguish between people. Once the human tiger is mature, all the people yield to his animal instincts. Since the dawn of history, Cane did not have mercy on Abel. Goneril and Regan did not have mercy on an aged father in a storm. Uday did not have mercy on his people even those in his palaces. Tiger himself eventually devours Tom's hand. Therefore, this is a proof of the new historicist nature of the play. It is a documentation of the present, yet affected by the past, and still is able to affect the future. The link is clear here between past, present, and future.

The tiger is chosen for its rare existence. This goes parallel to the American empire which, after the fall of the Soviet Union, enjoys now a rare supreme power as the unilateral and the only force of the world. The exceptionalism of the tiger runs parallel to the exceptionalism of the brutal American force. In addition, there is a difference between the literal zoo and the human zoo. In the literal zoo, tiger or brutal force needs no justification to transgress and prey on others. Yet, in the human jungle, at least on the face of it, justification is needed. This is the world of idealism which is propagated by the one power of the world to be as a cover to justify its aggression on other nations, like Iraq here or Vietnam before. As plea for the American interference in Iraq, the American go under an idealism 
humanistic mask to cover their hunger for power and wealth, which can only be got by usurping the Iraqi wealth.

Hence, joseph places spiritualism versus materialism. The spiritual world is symbolized by ghosts and the words that come out of conscience. Material of course is the talk of power, prey, and the instinctive desire to attack. The play dramatizes through this the continuous conflict between both worlds. However, the moment tiger attacks Tom, Joseph here alludes to the fact that savage power can be very destructive. He allows, soon after the attack, Tiger to change into a ghost. It is as if he wants to say that the moment materialism and savagery reaches the point of aggression against the self and suicide, its losses all the sources of being; i.e. it loses identity and that is why Tiger changes into a ghost soon after. Tiger says; "I won't lie. When I get hungry, I get stupid. I screwed up twelve years back. I just followed the scent, took a bite, and then, fhwipp!" (Act 1, Sc.1, 148). In this quotation, the tiger is a symbol of the greed and brutal American authority which resembles the tiger when he is hungry. Thus, the Americans are also hungry for the material interests in Iraq. Joseph creates many roles for the tiger.

Joseph is interested in how language is a form of power as well as how it is used for political and social control. Americans employ many Iraqi citizens as translator to facilitate communication between the military forces and Iraqi citizen, hoping to make cultural exchange. Musa's character as a translator serves the fact that thousands of Iraqis work as translator for the American since the first gulf war. Translation is the hammer which destroys the barriers among different cultures. Joseph is aware of the facts around the war, so, he tries to show each element to depict the reality. Musa is an important character in the play; he is the tool of building. He fills the gap between the two cultures where he is a victim of both sides of the conflict. $\mathrm{He}$ is the victim of Uday's tyranny and perfidiousness. Musa is the link between the forces of occupation and the Iraqi natives. The following quotation shows how Musa does his best to translate to remove the ambiguity of communication in the hardest situations for his native people during the American parades on the Iraqi houses.

Kev: Hey! What's in this chest here? Hey you speak English?

MUSA: They don't speak English! stop yelling! You don't need to yell.

Kev: That's what you gotta do, man, or these towelheads will fuck you, man.

MUSA: Just tell me what you want to tell them and I will translate. Okay? (Act 2, Sc., 165)

The analysis of the language of the play illuminates that Joseph is well acquainted with the Iraqi culture and language, especially in its 
colloquial form. This can be seen in the Iraqi colloquial expressions which can be seen everywhere in the play. For example, Act one, scene three begins with Iraqi woman words as follow:

Woman: (Arabic) Don't take him! Get out of our house! Leave us alone! La- Takthoo! Etle'oo min baitne! Joozoo min edne!

$$
\text { لاتاخدو ! اطلعو ا من بيتنه! جوزو من عدنة! Joseph 163, 2011) }
$$

Joseph's assigns an important role for Musa to refer to the idea of transition upon which the ideas and themes of the play depends. He wants to direct the audience's interest to the transitional case which happens in the world focusing the limit in the case of Iraq. He sees that there is a transition from peace to conflict and war, and from beauty and perfection to ruin, ugliness, distortion, and bizarre. This trait of transition from humanity to savage animalism is expressed about in Bengal Tiger through representing the scene of war with all its details. This world of war is depicted allegorically and is intertwined with realistic scene.

The American soldier in Act two, scene two, spoke in Iraqi colloquial. Ann Anderson writes that Joseph is interested to make actors speak "Iraqi Arabic, a discrete dialect also known as Mesopotamian Arabic. For the benefit of the production, Iraqi language consultants have transliterated the Arabic dialogue so that it's authentically Iraqi, and so nonArabic speaking actors can pronounce the words properly" (12). Andreson's words assure that Joseph is aware of the importance of removing the obstacles and the barriers between English language and the Arabic language. This interest of using the Iraqi language beside the English language in the text illuminates Joseph's desire in stirring a process of cultural negotiation. In this case, audience and readers need to exert extra activities to translate and interpret the performance or text through using imagination to detect the theatrical significance of the body language of the actors. Consequently, the text gained many chances of new interpretations which can be considered as new texts. This point can be linked to the importance of translation as "a celebration of the death and resurrection of the source language, as transcendental communication across spatial and temporal divides, and as an in-between space of linguistic and cultural negotiation" (Muneroni 1, 2011). Therefore, Kev's following words clarifies this point as follows:

KEV: (Arabic) I am lost in the desert.

Anee tayeh bil sahara'.

اني تايه بالصحر اء.

God, I am lost in the desert and I am calling out to you in prayer. Because I have never before prayed, I am prayer. Because I have never before prayed, I am praying to you in a 
different language because the very strangeness of it makes me feel like perhaps you would understand.

Ulleh, anee tayeh bil sahra' oo ed'eelek, anee b'oomree me di'ait gebul, bess hisse da ed'eelek bgair lugeh. A'roof hathe shee ghereeb bess emelee inoo tigder tiftehimnee.

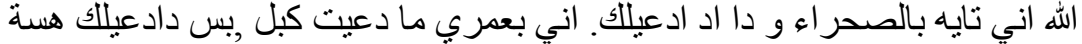

(Act 2, Sc.1, 222)

In the previous quotation, Kev's speaks Arabic language in a desperate tone. He seems to be in a need for divine forgiveness as he felt lost. In this situation, Joseph portrays that the place was bombed at night in Baghdad desert and the American soldier calls God and asks for His help in Arabic language. Stefano Muneroni defends this as follows:

It is through bilingualism that the play establishes a powerful connection with the religious concerns raised in the plot, mainly the quest for life's meaning and the role of God in human affairs. From an audience perspective, the play inscribes the experience of foreign language through xenoglossia, the ability to speak a language one has never learned, and glossolalia. $(6,2011)$

This linguistic conflict illuminates also the struggle of identity - to be an Arab or an American. Joseph's depiction of this struggle makes his characters seem to swerve in their question 'to be or not to be' - but not according to the meaning in Hamlet. Yet in Bengal Tiger, characters suffer the dilemma of 'To be a ghost of a victim or a slaughter', ' To be an Arab or an American', and 'To be postmodern man or to live in the cradle of civilization'. Therefore, this linguistic conflict is expressed about through the need of the translator character in the play. This point is not a sort of fictional property to configure the cultural conflict, but it is also a depiction of what happened on the factual ground.

Brutal force which was symbolized here by the tiger forms a kind of triangle with tiger on its head. As a result, both kev and Tom represented its tools and main base. Yet, the fact that Kev announces that he got Uday's gun would mean that brutal forces gets more power by devouring other minor forces like the Iraqi tyrant, Saddam, and his sons. Chelsea Butkowski considers that "a meditation on animalism and the legacies combat leaves behind "Bengal Tiger at the Baghdad Zoo" which doubles as a war story and a modern ghost story" $(11,2013)$.

Joseph gave an expression about the theme of death in life and life in death through the intermingling and weaving of life and death in the world of Bengal Tiger. This interprets the dead characters continual existence in the world of the live characters. The shared exercises of life between the dead and living characters, or the in-between mood of life, give an opportunity to 
link it to ghost haunting experience. This also can be interpreted as the ghostly haunting mood which prevails in the play and which reflects Joseph's desire in illuminating the liminal relation between life and death, present, past and future, and also between the geopolitical relation both on the individual and international standards. In other words, the relation between one's birth, death, and then new life in death in a foreign country rather than homeland can describe the transcendental limit of knowledge. In addition, it also hints to the international geo-political conflicts which affect the destiny of both persons and nations.

Presenting ghosts in theatre is an old dramatic tradition. It is a main component of theatre in the first eras of the history of drama. In classical periods, ghosts were not just ideas, but they are also characters. Since people believed in ghosts, this idea was connected to religion. Spanish Tragedy and Senecan ghosts are witnesses to this idea. In modern theatre, ghosts found a path in the drama of Henrik Ibsen, Edward Bond, and others. Ghosts also have a new return in postmodern theatre. However, the question is: do these ghosts have the same features of the classical ones?

To answer this question, one must think of the ghosts in Joseph's Bengal Tiger, the model of reading in this study, and then compare them to some examples of ghosts from the history of classical drama. In Joseph's play, tiger is used as a device to explore topics such as religion, the meaning of life, and the nature of violence. The play presents the savage animal as a scared one who is terrified of the afterlife. Probably, it is a call for the cruel and tyrant human beings to compare themselves to this animal. The tiger passes the experience of revelation and the audiences accompany him in the journey of existential quandary.

Tiger: I don't know why I'm so scared. You figure getting killed might be the last bad thing that can happen. The worst thing. I'll tell you right now: it's not the worst thing. See, all my life, I've been plagued, as most tigers are, by this existential quandary: why am I here? But now ...I'm dead, I'm a ghost ... and it's: Why have I not gone?

I figured everything just ended. I figured the Leos ... just ended. The suicidal Polar bear ... bones and dust. It's alarming, this life after death. The fact is, tigers are atheists. All of us. Unabashed. So, why am I still kicking around? Why me? Why here?

It doesn't seem fair. A dead cat consigned to this burning city doesn't seem just. (Act 1, sc.4, 175, 2011)

In the mess of war, the tiger ghost is astonished by the call for prayer. He asks many questions about atheism. He begins to search for God. He reaches that there is a God, the creator of the Garden of Eden. At the end, he 
gains salvation. It is a message for those who think that they are God and they can control and destroy everything. Joseph's presentation of the moral of the play seems to follow the steps of fairy tales. The tiger is represented as an observer and narrator. He is dressed as homeless in tattered clothes. $\mathrm{He}$ roams the urban landscape, searching for answers. The other ghost in the play is Uday's ghost who is sadistic. He is presented as equal to the tiger in his terrified nature and temper. Yet, there is an ironic contrast between Uday and the tiger which illuminates the message of the play. Uday lacks the adjectives of human being and has no conscience, while the tiger is obsessed by his conscience. Therefore, the play is an open dialogue among ghosts. In a conversation with Joseph by Marti Lyons, he says:

I see the play as more of ghost story than a war story. Because my story begins with a talking tiger being killed, his ghost becomes a necessary conceit for keeping his character alive. The play followed suit. But on a deeper level, I think ghost stories live inside of war stories. And I think America will be haunted by this war longer than we might think. (Fruend \& Lyons 2)

The ghost in Hamlet is presented in the play because it is the tradition of revenge plays. This is also in accordance with the philosophical and cultural nature of the Elizabethan age. The significance of the ghost in the play can be seen in these points. First, the ghost is the mover of the play's actions from the beginning to the end. The presence of the ghost would mean the existence of the roamer which is spreading in Denmark at that time and in England according to the new historicist view.

Thus, each writer has his view in presenting the ghost in drama. Bond uses the ghost for symbolic functions to cope with his political style. James Hudson notes that the ghost which is a real stage image in the drama of Bond " enables him to deal in abstractions ... the figure of the living dead, either spectral or reanimated becomes inhabited by metaphorical or emblematic significance and can be understood as being representative of broader theoretical and philosophical notions in Bonds" (12-13, 2013).

Yet, the belief in ghosts transmits the reader to the classical ages of history. Nevertheless, there are many studies which search the phenomena of the continuous belief in ghosts in the 21st century. In Haunting Experiences Ghosts in Contemporary Folklore, Diane E. Gol deduces that:

Three out of four Americans in the early twenty -first century have some sort of paranormal belief, which includes at least one of the following: "extra sensory perception (ESP), haunted houses, ghosts, mental telepathy, clairvoyance, astrology, communicating with the dead, witches, reincarnation, and channeling. There are no significant 
differences in belief by age, gender, education, or region of the country" (4).

This anecdote shows the circulation of the existence of ghosts in the 21 st century in all the classes of the American society. Greenblatt's 'desire to speak with the dead' comes up in a parallel line with the call for ghosts or what can be described as a postmodern turn of ghosts in literature. Furthermore, new historicist reading of text reckons on the present or through the dialogue between past and present through tracing the textual of the past in the text.

Hence, Joseph places spiritualism versus materialism. The spiritual world is symbolized here by the ghost and the words that come out of conscience. Materialism of course is the talk for power, prey, and the instinctive desire to attack. The play dramatizes through, but there was a continuous conflict between both worlds. Marla Carlson notices that "an animal identity provides a way out of human norms that have become unduly restrictive and often enough has nothing at all to do with animals" (195, 2011).

According to Carlson's words, animals' animation is a type of psychological policy or a camouflage in order to penetrate the obstacles to present a dramatic performance which is able to represent social and political criticism either for the family or the state. Reckoning on this point, one can see that Joseph adopts a similar tendency in his writings. In Bengal Tiger, the title is evocative and the protagonist of the play is an animal. The tiger is a symbol of the brutal power of the American, which is hoped to be subdued. Hence, the tiger is imprisoned in the play. The fact that it rebelled against its guards would be a reference to the American brutality that went out of control, hurting its people in a kind of self-destructive manner. Only lunatic power hurts against its people. The power of the tiger that is supposed to be directed against the Iraqi tyrant turns against the Americans themselves and punished them as well. Another fact that should be taken into consideration is that the tiger turned later on into a ghost. This means that the unjust power of the American lost reality and validity. As a consequence, it turned into a phantom that would remain as a nightmare to torture them for years to come. This is paralleled to Uday and his role in the play. Being the destructive power on the Iraqi side, these atrocities are manifestation. He killed the translator's sister, typical of the American administration which is the cause of the murder of thousands from both the Iraqis and Americans. Thus, the objective line of the end that all tyrant power meets is clear. They imagine that they are active and effective and can do a lot. However, in reality, their invalid and brutal action changes their realism into fantasy. They lost reality. The gap between their exceptionalism in what they think they can achieve 
and what they can actually managed to do causes the American psychological pain to culminate in the loss of identity. This is clear when Kev confesses that they "all have a psycho problem now, Tommy. Me and Tiger and you. And I'm gonna figure it out" (Act 1, Sc.2, 214).

Uttara Choudhury (2007) says "Joseph feels his magic realist work will not touch a raw nerve with American families who have lost loved ones in Iraq" (8). She pinpoints to the vulgar oppression and killing of children by the American occupation. Choundhury makes a comparison between the tiger who justifies his cruelty because of his nature and his need for food. Yet, for the Americans, killing is not justified. She clarifies that: At one point, the tiger talks about cruelty and how years ago, when he was living in the Sundarbans, he killed two children. He ate them and caused misery to the parents. But he insists it wasn't cruel, it was lunch. Yet, now children are being killed in Baghdad for no reason half as good as lunch $(8,2007)$.

Subsequently, the practice of "poetics of culture" is interested in the relationship between the referential realities and literary and historical writing. The text is always composed of referential realities and historical facts. These words draw the new historicist reading of Bengal Tiger to assume that the play can be described in a journalistic way of writing in two headlines: From the Garden of Eden to the Pool of Ghosts and The Journey of Ruin under the Veil of the Mission of Freedom. Metonymy is the relationship between a signifier and signified. Iraq is related to sacred event as the place denotes an event mentioned in the Bible. The Bible is the reference to the literary text, but the relation between the two (the signifier and the signified) is metaphorical.

Bengal Tiger does not only include historical references and allusions which imply its exclusive nature, but it can also be seen as a counterpart for other literary creative forms. Picasso's Guenerica presents an example of the idea of pairing two different literary works as follows.

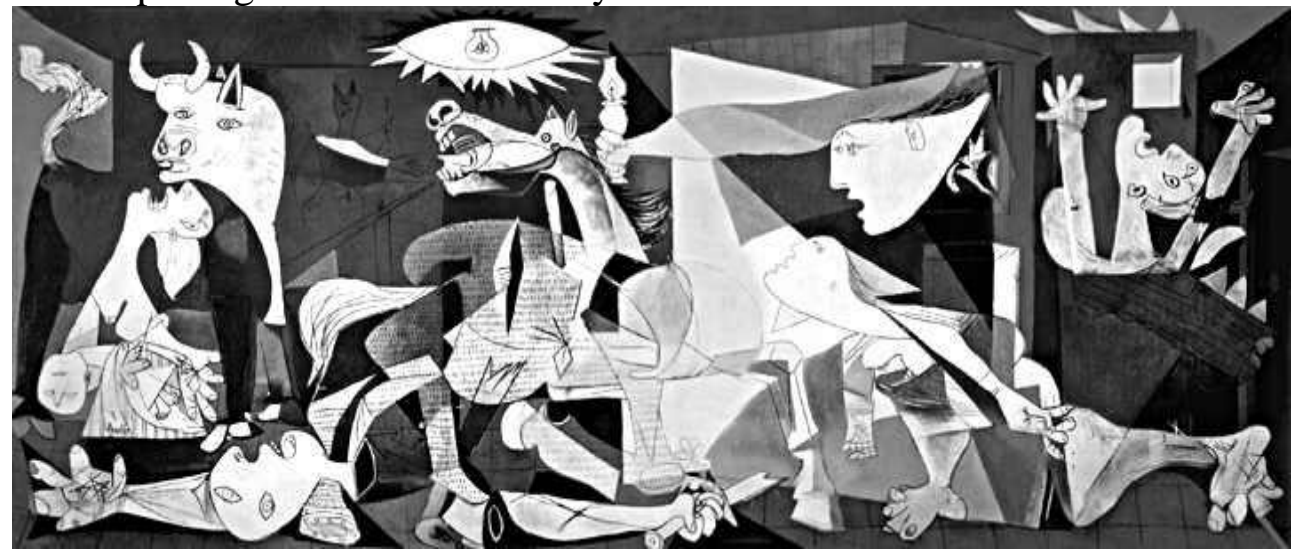

Picasso's Guernica 
Bengal Tiger seems to be the extension of Picasso's Guernica. If the reader allows him/herself a space of imagination, he will find that both of the literary works are two chapters of the history of violence. Therefore, it can be said that there is a parallelism between the two works in the depiction of the atrocities of war. The first work is an embodiment and representation of the invasion on Iraq, while the second represents the destruction of the town of Guernica by air raiders. Joseph draws his pictures by his theatrical writing. His brave skill makes a surreal painting from words. On the other hand, Picasso's painting seems to contain persons, animals who can speak, and is able to narrate the details of awful event of atrocity. So, the play can be seen as a painting of a skillful artist and at the same time, the painting can be viewed as analogous to theatrical performance.

In conclusion, it can be said that ghost is a representative of many figures such as: Saddam, the forces of occupation, the voice of wisdom, and the innocent victim of war. Perhaps, Joseph's title is not so ambiguous right now. Bengal Tiger contains the elements of tragicomedy such as the doomed fate of characters being ended as ghosts and the features of surrealistic comedy depicted in the personalization of an animal. Here, the play encourages its reading as multi-layered work. As such, it is an interrogative drama. The play is a portrait of intertwined fact and fiction. It helps the reader and audience to question not only the fiction in the official history about the Iraqi war, but also the realism in them. It is a representation of history as a form of fiction which reflects the new historicist view which does not accept treating the text as the only element in the ideology of the age.

\section{References:}

1. Anderson Ann. Between the Lines. Center Theatre Group: L.A.S' Theatre Company.

2. Bressler Charles E. (2011). Literary Criticism: an Introduction to Theory and Practice, thrd, edition Longman.

3. Butkowski Chelsea(2013). '"Bengal Tiger' Recounts Haunting Wartime Realities from Student Perspective". The Lamron: Geneseo's Student Newspaper. Vol. XCIII, 7. Pp.1-20

4. Carlson Marla (2011). "Furry Catography: Performing Species". Theatre Journal $63,191-208$ (C) by The Johns Hopkins UP

5. Choudhury Uttara. (2007). " New York Playwright Tells an IraqCentric Orwellian Story". Beyond Borders. dna,Sunday

6. Fruend, Jake \& Marti Lyons. "Bengal Tiger at the Baghdad Zoo Discussion Guide". Looking Glass. 25 ${ }^{\text {th }}$ Anniversery Season, 1-13. 
7. Hudson James ( 2013). "Absent Friends: Edward Bond's Corporeal Ghosts". Platform, vol.7, 1.

8. Joseph Rajiv (2010). Three Plays: Gruesome Playground Injuries, Animals Out Of Paper \& Bengal Tiger at the Baghdad Zoo, Soft Skull Press.

9. Myers, D.G. (winter 1988-89)."The New Historicism in Literary Studies". Academic Questions. pp.27-36.

10. Muneroni Stefano(2013). "Translational Eschatology, Death, and the Absence of God in Rajiv Joseph's Bengal Tiger at the Baghdad Zoo". International Journal of Creative Literature \& Translation Studies Vol. 1, 2, pp.1-10.

11. Raymond Gerald (2011). "Lost and Found in Translation: an interview with Rajiv Joseph ". April 3, Theatre interviews. www.slantmagazine.com 